Canadian University Music Review

Revue de musique des universités canadiennes

\title{
Richard Langham Smith, ed. Debussy Studies. Cambridge: \\ Cambridge University Press, 1997. xvi, 235 pp. \\ ISBN-0-521-46090-5 (hardcover)
}

\section{Richard S. Parks}

Volume 20, numéro 2, 2000

URI : https://id.erudit.org/iderudit/1014468ar

DOI : https://doi.org/10.7202/1014468ar

Aller au sommaire du numéro

Éditeur(s)

Canadian University Music Society / Société de musique des universités canadiennes

ISSN

0710-0353 (imprimé)

2291-2436 (numérique)

Découvrir la revue

Citer ce compte rendu

Parks, R. S. (2000). Compte rendu de [Richard Langham Smith, ed. Debussy

Studies. Cambridge: Cambridge University Press, 1997. xvi, 235 pp.

ISBN-0-521-46090-5 (hardcover)]. Canadian University Music Review / Revue de

musique des universités canadiennes, 20(2), 129-132.

https://doi.org/10.7202/1014468ar

All Rights Reserved @ Canadian University Music Society / Société de musique des universités canadiennes, 2000
Ce document est protégé par la loi sur le droit d'auteur. L'utilisation des services d'Érudit (y compris la reproduction) est assujettie à sa politique d'utilisation que vous pouvez consulter en ligne.

https://apropos.erudit.org/fr/usagers/politique-dutilisation/ 
Richard Langham Smith, ed. Debussy Studies. Cambridge: Cambridge University Press, 1997. xvi, 235 pp. ISBN-0-521-46090-5 (hardcover).

Debussy research has seen a flurry of activity lately. Recent releases in the critical edition of the composer's works include $\mathrm{La} \mathrm{mer}{ }^{1}$ and various piano works including the Images of 1894, Pour le piano, and Children's Corner. ${ }^{2}$ In addition, there is Tresize's monograph on La mer, and Nichol's brief biography. ${ }^{3}$ Moreover, Cambridge University Press could well be nicknamed "CambridgeDebussy Press" since it is the publisher of the aforementioned studies as well as the volume that is the subject of this review. ${ }^{4}$ Most of the nine essays in this collection are concerned either with issues arising from holograph materials or address various contextual issues surrounding the composer's life and work. I shall begin with the three chapters that fall in the first category.

In "The Definition of Timbre in the Process of Composition of Jeux," Myriam Chimènes, ${ }^{5}$ identifies three extant holographs for Jeux: a particelle, a piano "reduction," and the préparation orchestrale. She dates the composition of a complete draft of the work from sometime after 2 July 1912 to 25 August, which is astonishingly swift, but even more intriguing is her conclusion regarding the place of orchestration in the compositional process: by comparing parallel excerpts of passages from the holographs with the published score, she demonstrates that, at least in Jeux, orchestration occurred almost entirely as a separate, late stage. This assertion contradicts long-held notions that for the mature Debussy, timbre and orchestration were integral to composition from the beginning. ${ }^{6}$

Denis Herlin's subject ("Sirens in the Labyrinth: Amendments in Debussy's Nocturnes") is Debussy's many emendations found in two copies of this triptych's score. The two scores are the so-called François Lang and Roger-Ducasse copies (both named for their owners). In brief, Herlin explains that annotations and emendations substantially alter the original published version of 1900 , but they also contradict each other. As well, the "new edition" of 1930 published by Jobert comprises a sort of selective culling of changes from both the aforementioned scores. The result is that, on one hand, most modern performances based

\footnotetext{
${ }^{1}$ Claude Debussy, CEuvres complètes de Claude Debussy, Series 5, vol.5 (Paris: Durand-Costallat, 1997).

${ }^{2}$ Debussy, Euvres complètes, Series 1, vol. 2 (1998).

${ }^{3}$ Simon Tresize, Debussy: "La Mer," Cambridge Music Handbooks (Cambridge: Cambridge University Press, 1994); Roger Nichols, The Life of Debussy, Cambridge Musical Lives (Cambridge: Cambridge University Press, 1998).

${ }^{4}$ Other important books about Debussy published by Cambridge University Press include: Edward Lockspeiser, Debussy: His Life and Mind, 2 vols. $(1962,1965)$, which remains the most comprehensive biography; Robert Orledge, Debussy and the Theatre (1982); Roy Howat, Debussy in Proportion: A Musical Analysis (1983); and Roger Nichols and Richard Langham Smith, Claude Debussy: "Pelléas et Mélisande," Cambridge Opera Handbooks (Cambridge: Cambridge University Press, 1989).

${ }^{5}$ Chimènes is the co-editor (with Pierre Boulez) of the critical edition of Jeux that appears in the complete works. Claude Debussy, Euvres complètes, Series 5, vol. 8 (1988).

${ }^{6}$ The youthful Pierre Boulez was one of the most prominent proponents of this argument. See his essay "Claude Debussy," in Stocktakings from an Apprenticeship, ed. Paule Thévenin, trans. Stephen Walsh (Oxford: Clarendon Press, 1991), 259-77, especially p. 274.
} 
on the 1930 Jobert edition are based on a text that is flawed by inconsistencies and incomplete revisions; on the other, there is no easy way out through the production of a new critical edition (now underway by Herlin), especially for "Sirènes," which has the most changes, since the scores must be regarded as equally authoritative but contradictory sources. This illuminating chapter calls to mind Grayson's extensive examination (see note 9 below) of post-publication vocal and full scores of Pelléas et Mélisande containing copious changes by the composer that engender similar dilemmas for critical editors and performers.

Over twenty years ago the pianist Paul Jacobs asserted that certain aspects of technical interpretation long considered enigmatic, including pedalling, articulation, and the use (or avoidance) of rubato could be resolved by reference to contextual facts and artifacts, such as the mechanical features of Debussy's pianos (the absence of a sostenuto pedal, for example). ${ }^{7}$ Jacobs's iconoclastic ideas were supported by persuasive performances that called into question the rather dry performance practice that had evolved in the years following Debussy's death. But Jacobs was first and foremost a performer, less a careful scholar, and some of his ideas were inconsistent or extrapolated beyond the authority of his evidence. Enter Roy Howat, a knowledgeable and meticulous scholar as well as an admirable performer. Editor of several volumes of piano music in the emerging critical edition of Debussy's works, in "Debussy's Piano Music: Sources and Performance" Howat brings his keen grasp of the details of Debussy holographs, editions, and documents as well as his long experience as a performer to bear on editorial and interpretative problems of rhythm, tempo, articulation, and dynamics. ${ }^{8}$ Apropos of rhythm, Howat believes that Debussy's often idiosyncratic notations arose as pragmatic solutions to convey highly complex musical intentions, and he supports his assertion with several persuasive examples. In contrast, apparent anomalies in tempo and articulation sometimes may be due to contemporaneous conventions, which Debussy could assume performers would understand, but which may be unknown or counterintuitive for today's performers. In the realm of dynamic markings, the author compares holographs with published versions where the notation is substantially different. He surmises that engravers made alterations in order to bring Debussy's original notation into conformity with conventional engraving practices, but because the original idiosyncratic notation sought to clarify lines or emphasize musical events, the result is a loss of musical meaning. Howat's command of notational details in the piano music is formidable, and together with his many practical suggestions he casts much light into heretofore darkened corners.

There is a twofold subject for David Grayson's chapter, "Waiting for Golaud: The Concept of Time in Pelléas." The author first addresses Maeterlinck's treat-

${ }^{7}$ I heard Jacobs deliver a perspicuous lecture-demonstration on the subject at the combined AMS-SMT annual conference in Minneapolis, in 1978, which he later published as "On Playing the Piano Music of Debussy," Cahiers Debussy, n.s. 3 (1979): 39-44.

${ }^{8}$ To date Howat has edited three volumes of piano music for the critical edition: Debussy, Préludes, Books I and II, with the assistance of Claude Helffer, CEuvres complètes, Series I, vol. 5 (1985); Estampes, D'un cahier d'esquisses, Masques, L'isle joyeuse, Images 1st series, Images 2nd series, Series I, vol. 3 (1991); Images (1894-dédiées à Y. Lerolle), Pour le piano, Children's Corner, Series I, vol. 2 (1998). 
ment of chronological time in the drama, proceeding from the observation that the playwright's story about the characters in the land of Allemonde is expressed (via the technique of flashback) as a recounting of something that has already occurred. Since the recounting itself is already set in the past the drama becomes a double conceit, a story within a story. Debussy's substantial alterations made in constructing the libretto, including excisions of several scenes, have the effect of stripping off the outer shell of the nearer past temporality (in relation to which the story itself takes place in a still deeper past), thereby removing a layer of narrative from the drama and leaving a more straightforward story set simply in some undefined past. ${ }^{9}$ This essay is mainly concerned, however, with what might be called "dramatic time" in the opera-the way the passage of time is treated by unfolding events, and also by characters' recounting of their experience of it. Here, as always, Grayson writes engagingly about the myriad details of drama and music, from which this sense of "dramatic time" emerges.

Debussy's fondness in the visual arts for the work of J. M. W. Turner, James McNeill Whistler, Katsushika Hokasai, and Claude Monet is well known. However, there are other, less well-known artists who also attracted his interest and admiration. Jean-Michel Nectoux, in "Portrait of the Artist as Roderick Usher," focuses upon Debussy's predilections for the works of several far less prominent visual artists, including Henry Lerolle (1848-1929), who was an important contact for the young composer during his formative years immediately after his return from Rome. Nectoux also mentions Fritz Thaulow (1847-1906), a Norwegian artist whom Debussy came to know through Lerolle, and Edgar Degas (1834-1917), as well as Henry de Groux (1866-1930) and Camille Claudel (1864-1943). The latter two artists' works exhibit a quality of wildness, almost recklessness, as well as a mastery of the medium of sculpture. Nectoux suggests that Debussy was drawn to these artists and their work because he shared their aesthetic disregard for academic rules and training.

Roger Nichols's "The Reception of Debussy's Music in Britain up to 1914" and Robert Orledge's "Debussy and Satie" are both engaging chronicles, the first concerned with Debussy reception during the period 1901-14 through accounts of reviewers and others (such as the conductor Henry Wood), the second recounting the history of Debussy's longest friendship told through the principals' sparse correspondence and more numerous accounts of friends and acquaintances.

"Semantic and Structural Issues in Debussy's Mallarmé Songs," by Marie Rolf, is the only chapter with theoretical-analytical content. This study examines closely interrelations between music and text in two songs setting poems by Stéphane Mallarmé, "Apparition" and "Soupir." While the poems are proximate in Mallarmé's output (written ca. 1863-64), Debussy's marvellous song settings span nearly thirty years, with "Apparition" composed in 1884, and "Soupir" in 1913. What Rolf demonstrates brilliantly is Debussy's enormous growth, both in his grasp of nuance and multifaceted meaning of Mallarmé's

\footnotetext{
${ }^{9}$ Grayson thoroughly explores the relationship between Maeterlinck's play and Debussy's adaptation for his libretto in his book, The Genesis of Debussy's "Pelléas et Mélisande," Studies in Musicology, no. 86 (Ann Arbor, Mich.: UMI Research Press, 1986).
} 
texts (including their forms), and in his ability to enlist equally multifaceted musical resources to produce musical settings that profoundly and subtly enhance them without in any way distorting or obscuring. A distraction is her voice-leading sketches of portions of "Apparition" (examples 8.2, p. 186 and 8.5 ,p. 190), which are somewhat puzzling to decipher. In example 8.2 , for example, we are directed to note a "tenuous linear progression" (p. 185), which is generally understood to mean a stepwise diatonic motion in a single voice that connects two tones belonging to a single harmony (customarily notated as stemmed notes connected to a single beam), but such a structural interval (supported in the bass) is nowhere to be found; moreover, while the beginning of the figure shows $\mathrm{E}^{4}$ supporting G-sharp and $\mathrm{B}$ (-natural) above, it is beamed as an interval within a single harmony to B-flat ${ }^{3}$. This minor complaint aside (and these examples really are incidental to the discussion) this estimable article is a model for critical studies of text settings.

Richard Langham Smith's chapter (“'La jeunesse du Cid': A Mislaid Act in Rodrigue et Chimène") falls somewhere between "autograph studies" and "contextual issues," treating the subject of Debussy's early, unfinished opera, and in particular its outer form of three acts with four tableaux. Since Catulle Mendès's pronouncements to the Paris press declared there would be four acts with five tableaux, the question to be answered is whether there is a missing act to Debussy's extant holographs. Langham Smith reviews the Spanish and French literary sources that treat the Cid legend, alongside Mendès's comments, and concludes that there must have been another act, which has since been lost.

This uniformly strong collection of important essays by a group of well-known Debussy researchers is "must" reading for fin-de-siècle specialists, but it will also attract a much wider audience of scholars and music lovers. Its emphasis on "the music's context" cries out for a complementary collection of theoretical-analytical essays to treat "the music itself." Fortunately, such a volume is presently underway in the form of a Debussy Companion under the editorial direction of Simon Tresize (yet another Cambridge University Press project).

Richard S. Parks

Kathryn Bailey, ed. Webern Studies. Cambridge: Cambridge University Press, 1996. xix, 375 pp. ISBN 0-521-47526-0.

Webern Studies, edited by Kathryn Bailey, commemorates the fiftieth anniversary of Webern's death in 1945 with a collection of nine essays whose subject matter encompasses the composer's entire creative life and more. Six of the essays pursue analytical and critical studies of individual works or small groups of works: youthful vocal compositions predating his studies with Schoenberg (Rode-Breymann); early atonal works (Forte, Wason, Meyer and Shreffler); and mature works in the twelve-tone idiom (Wintle, Whittall). The three remaining essays contribute in rather different ways, both critical and practical, to Webern scholarship: one speculates with tongue in cheek on the fictive question of what might have transpired had Webern not relinquished the post-romantic idiom of 